IZA DP No. 9309

Want Freedom, Will Travel:

Emigrant Self-Selection According to Institutional Quality

Maryam Naghsh Nejad

Andrew T. Young

August 2015 


\title{
Want Freedom, Will Travel: Emigrant Self-Selection According to Institutional Quality
}

\author{
Maryam Naghsh Nejad \\ $I Z A$ \\ Andrew T. Young \\ West Virginia University
}

Discussion Paper No. 9309

August 2015

IZA
P.O. Box 7240
53072 Bonn
Germany
Phone: +49-228-3894-0
Fax: +49-228-3894-180
E-mail: iza@iza.org

\begin{abstract}
Any opinions expressed here are those of the author(s) and not those of IZA. Research published in this series may include views on policy, but the institute itself takes no institutional policy positions. The IZA research network is committed to the IZA Guiding Principles of Research Integrity.

The Institute for the Study of Labor (IZA) in Bonn is a local and virtual international research center and a place of communication between science, politics and business. IZA is an independent nonprofit organization supported by Deutsche Post Foundation. The center is associated with the University of Bonn and offers a stimulating research environment through its international network, workshops and conferences, data service, project support, research visits and doctoral program. IZA engages in (i) original and internationally competitive research in all fields of labor economics, (ii) development of policy concepts, and (iii) dissemination of research results and concepts to the interested public.
\end{abstract}

IZA Discussion Papers often represent preliminary work and are circulated to encourage discussion. Citation of such a paper should account for its provisional character. A revised version may be available directly from the author. 


\section{ABSTRACT \\ Want Freedom, Will Travel: Emigrant Self-Selection According to Institutional Quality*}

We investigate emigrant self-selection according to institutional quality using up to 3,566 observations on bilateral migration flows from 77 countries over the 1990-2000 period. We relate these flows to differences in political and economic institutions. We improve and expand upon previous studies by (i) examining decade-long migration flows that (ii) include flows not only to OECD countries but also to non-OECD countries; also (iii) utilizing an estimation method that takes into account the information in zero value migration flows and (iv) examining not only total migration flows but also college-educated and non-college educated subsamples separately. We find that economic freedoms are a significant pull factor for potential migrants. Once economic freedoms are controlled for, measures of political institutions do not enter significantly into our estimations. Results are similar for college- and non-college-educated subsamples. Improvements in legal systems and property rights appear to be the strongest pull factor for potential migrants.

JEL Classification: $\quad$ O43, F22, P51

Keywords: emigration, institutions, democracy, economic freedom, brain drain

Corresponding author:

Maryam Naghsh Nejad

IZA

P.O. Box 7240

53072 Bonn

Germany

E-mail: Naghshnejad@iza.org

\footnotetext{
* We thank the participants at the Arnoldshain seminar, the economic seminar of American University of Beirut, and the 2015 Public Choice Society meetings for their valuable comments.
} 
Give me your tired, your poor, Your huddled masses yearning to breathe free, [...]

Emma Lazarus, “The New Colossus”, 1883

\section{Introduction}

Engraved within the pedestal of the Statue of Liberty in New York Harbor, Emma Lazarus’ sonnet expresses both the idea that conventional economic "pull” factors (e.g., income per capita) determine migration flows into a country as also the more romantic notion that potential emigrants are "yearning to breathe free”; that they will leave their homelands in search of liberty. Economists are not known to be particularly romantic. They are more likely to express Lazarus' notion in terms of emigrant self-selection according to institutional preferences.

Only a handful of studies explore the role of self-selection according to institutional quality in determining international migration (e.g., Karemara et al., 2000; Vogler and Rotte, 2000; Melkumia, 2006; Bertocchi and Strozzi, 2008; Ariu et al., 2014; Poprawe, 2015). However, there are good reasons to think that improvements in institutional quality are an important pull factor. Freedoms may be intrinsically valued as an input to subject well-being (e.g., Stiglitz et al., 2009), and studies have documented that they are positively associated with individuals’ self-reported happiness even after controlling for income (Ovaska and Takashima, 2006; Gehring, 2013; Nikolaev, 2014; Nikolova and Graham, 2015).

In this paper we ask whether economic and political freedoms of potential destinations relative to origins are significant determinants of migration decisions. We employ crosscountry data on up to 3,566 bilateral migration flows from 77 countries during the 1990 to 2000 period. We relate these flows to measures of institutional quality in potential destinations relative to origin countries. We use the Polity IV (Marshall and Jaggars, 2010) and checks and balances (Keefer and Stasavage, 2003) measures of political institutions, and 
the Fraser Institute's Economic Freedom of the World (EFW) index as a measure of economic institutions (Gwartney et al., 2014). ${ }^{1}$

Ashby (2010) examines a cross-section of bilateral migration stocks for 58 countries, and also migration flows to OECD countries between 2001 and 2006. He reports that economic freedom differentials are positively associated with bilateral migrations. Political freedom, alternatively, does not enter Ashby’s regressions positively when economic freedom is controlled for.

Our results are consistent with those of Ashby (2010). Furthermore, they are based on a substantially larger sample that includes migration flows from non-OECD countries to other non-OECD countries. The larger sample allows us to report separate effects for destinationorigin differential in each of the EFW index's constituent areas. We report that migrants are attracted to destinations with sounder currencies, less burdensome regulations, and stronger property rights and legal systems. The estimated effect on the latter EFW area (property rights and legal systems) is particularly large.

We also report results for college-educated and non-college-educated subsamples. In doing so, we ask whether differentials in institutional quality are contribute importantly to “brain drain” vis-á-vis more conventional pull factors such as income differentials. Outflows of human capital can directly lead to lower productivity in an origin country; also indirectly if the economy's ability to innovate and adopt new technologies is decreased (Marchiori et al., 2013). ${ }^{2}$ However, we report that greater economic freedom appears to be equally attractive to non-college-educated and college-educated migrants. Furthermore, controlling for economic freedom, the destination-origin income differential has a considerably larger estimated effect on college-educated migration.

\footnotetext{
${ }^{1}$ To check robustness and make the results comparable to some previous studies we also employ the Freedom House political freedoms and civil liberties scores.

2 See Docquier and Rapoport (2012) for a review of the literature on brain drain.
} 
This paper is organized as follows. In section 2 we discuss our contribution in relation to existing literature. We discuss our empirical model and the data that we employ to estimate it in section 3. In section 4 we report our results and then concluding comments are the stuff of section 5 .

\section{Our Contribution and the Existing Literature}

Only a handful of previous papers empirically examine emigrant self-selection according to institutional preferences. Karemara et al. (2000) and Melkumia (2006) report that measures of civil and economic freedom, respectively, in an origin country negatively predict emigration to the US. Vogler and Rotte (2000) report a similar result based on a measure of political freedom and migration from 86 Asian and African countries to Germany. ${ }^{3}$ Ariu et al. (2014) and Poprawe et al. (2015) examine differences in the quality of governance and corruption in relation to migration flows. Finally, papers by Bang and Mitra (2011), Baudassé and Baziller (2014), Naghsh Nejad (2013), Ferrant and Tuccio (2013), and Naghsh-Nejad and Young (2015) assess the role of women’s rights provisions in determining, specifically, female migration flows.

The paper closest to the present study is Ashby (2010) who examines a cross-section of bilateral migration stocks for 58 countries, and also annual migration flows to OECD countries between 2001 and 2006. He employs the Fraser Institute’s Economic Freedom of the World (EFW) scores and Freedom House's political freedom scores as institutional measures. He reports that economic freedom differentials between destination and origin

\footnotetext{
${ }^{3}$ Bang and Mitra (2009) report that, for emigrants to the US, the extent of corruption in the origin (measured by the International Country Risk Group (ICRG) index) negatively predicts migration. Bertocchi and Strozzi (2008) assemble a panel of migration flows to 14 countries (today in the OECD) during 1870-1910 and present evidence that high-quality political institutions served to attract migrants.
} 
countries positively predict bilateral migrations. Alternatively, political freedom is not a significant correlate once either income or economic freedom differentials are controlled for. ${ }^{4}$

We extend and improve upon Ashby’s study in a number of ways. First, we examine a cross-section of bilateral migration flows for up to 77 countries over a ten-year period (19902000). This is a larger sample of countries and, more importantly, examining migration flows is preferable. We would like to know how relative institutional qualities relate to migrant choices during a corresponding time period. Ashby acknowledges this and examines flows in his panel analysis. However, Ashby’s panel has a less-than ideal annual frequency. In addition to cyclical variation in migration flows, annual variation in institutional measures is likely to have a large noise component. (At least in any meaningful sense, the "rules of the game” - North, 1990, p. 3 - evolve a bit more slowly.)

Second, our data include not only migration flows to OECD countries, but also OECD to non-OECD flows as well as intra-non-OECD flows. OECD countries tend to have relatively high scores on measures of both economic and political institutions. Focusing on migration flows to OECD countries put a large emphasis on relatively large institutional quality differentials. Our data allows us to explore whether Ashby’s reported correlations are robust to including more variation from relatively finer cross-country differences in economic and political institutions.

Third, in addition to OLS estimates we report Poisson pseudo-maximum likelihood (PPML) estimations as suggested by Silva and Tenreyro (2006). This approach has been employed by recent studies to utilize bilateral migration observations that have zero values. These zero value observations are meaningful. For example, during 1990-2000 there was zero net migration from the US to the Central African Republic. Without utilizing PPML (or some

\footnotetext{
${ }^{4}$ Ashby (2007) provides a similar study based on migration flows across the contiguous US states and employing the Economic Freedom of North America (EFNA) index (Karabegovic et al., 2005).
} 
other alternative estimation method) this observation must be discarded. However, the fact that no US citizen chose to move to the DRC certainly has the potential to inform us about how people value institutional quality. Also, during 1990-2000 there was no net migration from India to Kenya. That zero value observation may tells us something about how factors other than relative institutional qualities affect migration decisions. In either case, getting an accurate picture of emigrant self-selection according to institutional quality involves taking that variation into account.

Fourth, in all of our estimations we control for "multilateral resistance”, i.e., the influence of alternative destinations on migration to a particular destination (Bertoli and Fernández-Huertas Moraga, 2012 \& 2013). When the influence of alternative destinations is ignored, the result can be to overestimate the importance of other observable characteristics (Bertoli and Fernández-Huertas Moraga, 2013; Bertoli et al., 2013). For example, migration from Nicaragua to Mauritius is rare. The 1990 EFW scores of Nicaragua and Mauritius are, respectively, 2.75 and 6.06. It would likely be wrong to conclude that few individuals move from Nicaragua to Mauritius because they do not care, all else equal, about the fact that they are relatively lacking in economic freedom. Controlling for multilateral resistance amounts to specifying certain groups, or nests, of countries and interacting origin country and nest fixed effects in the estimations. Intuitively we account for the fact that, all else equal, intra-Latin American migration is simply more likely to occur than migration from Latin America to Sub-Saharan Africa. ${ }^{5}$

Finally, we estimate the effects of economic and political freedom on, separately, college-educated and non-college-educated migration flows. Positive selection of high-skilled

\footnotetext{
${ }^{5}$ Multilateral resistance refers to the influence of alternative destinations on migration to a particular destination. In the Nicaragua-Mauritius example, we are controlling for the fact that if someone from Nicaragua is thinking of moving to Mauritius because it has more economic freedom, there choice will likely be (negatively) influenced by the fact that comparable gains in economic freedom are available by migration to alternative destinations in Latin America, e.g., Costa Rica (1990 EFW score = 6.64).
} 
emigrants is well documented and questions regarding the determinants of "brain drain" are critical for developing economies. Brain drain negatively impacts an economy’s ability to innovate and adopt new technologies (Marchiori et al., 2013). ${ }^{6}$ Selection of high-skilled migrants may be based on factors such as distance from origin, former colonial relationships, inequality in the origin, and cultural and linguistic proximity (Docquier, 2006; Brückner and Defoort, 2009; Belot and Hatton, 2013). Importantly, high-skilled, more educated individuals may have better information about the institutional quality of potential destinations. They also may be better able to reckon ex ante the value that they will place on them ex post. While we study the effect of institutional quality on migration decisions, those decisions may have important effects on the likelihood of institutional change in the origins (Docquier et al., 2014). When an origin's institutions are misaligned with its citizens' preferences, those individuals can choose to exercise either their voice or their exit option (Hirschman, 1970, 1990). In the case of the former, individuals seek to affect institutional change in their origins. Alternatively, individuals can exit and migrate to a different country with institutions aligned more closely to their preferences. On the one hand, exiting is a substitute for institutional change in the home country. On the other hand, exiting may also put individuals in an institutional setting where they are more able to express their dissatisfaction with origin institutions and lobby for change. Docquier et al. (2014) indeed find that emigration is associated with increases in the political and economic freedoms available in the origin country. Relatedly, Lodigliani and Salamore (2012) report that total immigration to destinations with greater political empowerment of women is associated with greater political participation of women in the origin country. ${ }^{7}$

\footnotetext{
${ }^{6}$ Docquier and Rapoport (2012) provide review of the literature on brain drain.

${ }^{7}$ Spilimbergo (2009) finds that returning emigrants who obtain education while in democratic destinations tend to promote democratic reforms in their origins.
} 
The above-cited studies are interesting in their own right and also raise concerns for endogeneity in our own study. To alleviate endogeneity concerns in general, we control for three types of fixed effects (origin, destination, and origin interacted with nest). In regards to reverse causation in particular, the above-cited studies suggest that migration positively affects origin institutional quality. Furthermore, other researchers have suggested that migration negatively affects destination institutional quality, especially when migration comes from lower institutional quality origins (e.g., Borjas, 2014 \& 2015; Collier, 2013). ${ }^{8}$ If these suggestions are accurate, then they will bias our results against finding that destination relative institutional quality is a positive determinant of migration.

\section{Empirical Model and Data}

We estimate gravity models of the forms,

$$
\ln \left(\text { Migration }_{i j s}\right)=\beta_{i}+\beta_{j}+\beta_{i * n}+\beta_{1}(\text { Institutions_Gap } i j)+\beta_{Z} Z_{i j}+\varepsilon_{i j} .
$$

Migration $_{i j s}$ is the bilateral migration flow from origin $i$ to destination $j$ of individuals of education level s. In the context of our data, s will correspond to all (or total), collegeeducated, or non-college educated. $\beta \mathrm{i}, \beta_{\mathrm{j}}$, and $\beta_{i * n}$ are origin, country, and origin-nest interaction fixed effects. (The "nests" will be defined below.) The error term is $\varepsilon_{i j}$.

A bilateral migration flow is measured as,

$$
\text { Migration }_{i j s}=\text { Stock_of_Migrantsijs, } 2000-\text { Stock_of_Migrantsijs, } 1990 .
$$

These observations are net flows over the 1990-2000 period. All migration data comes from the data set described by Docquier et al. (2009). Note that we do not scale migration flows by origin population. This is standard in the literature; fixed effects capture the population

\footnotetext{
${ }^{8}$ Clark et al. (2015), alternatively, present evidence from cross-country data that migration is associated with, at best, positive impacts on destination economic freedom and, at worst, no negative impacts.
} 
effects. (Recent examples include Beine et al. (2011), McKenzie et al. (2013), and Ortega and Peri (2013)).

Migration flows are related to a vector of gaps in measured institutional quality between destinations and origins, Institutions_Gap $\mathbf{G}_{\mathbf{i j}}$, where an element of this vector is constructed as,

$$
\text { Institution_Gap }_{i j}=\frac{\text { Institution_Measure }_{j, 1990}}{\text { Institution_Measure }_{i, 1990}} \text {. }
$$

Our institutional measures are (a) Polity IV democracy scores (Marshall and Jaggars, 2010), (b) checks and balances measures from Keefer and Stasavage (2003), and (c) the Fraser Institute’s Economic Freedom of the World scores (Gwartney et al., 2014). The Polity IV democracy and checks and balances measures are based on dimensions of political institutional quality. Democracy places particular emphasis the recruitment of and the constraints placed on the executive branch of a government. It is based on a scale of 0 to 10 , with 10 representing the highest quality of political institutions. ${ }^{9}$ Checks and balances, alternatively, is based on data from the Database of Political Institutions (DPI) (Beck et al., 2010) on the number of "veto players" (i.e., decision-makers whose agreement is necessary for a policy change to occur) that exist in a country's political system. A higher checks and balances score corresponds, like Polity IV, to greater restraint on government. ${ }^{10}$

The Economic Freedom of the World index is constructed on five equally weighted components: (i) government size, (ii) legal structure and property rights, (iii) access to sound money, (iv) the freedom to trade internationally, and (v) the regulation of markets. This measure is a comprehensive indicator of the quality of economic institutions and policies.

\footnotetext{
${ }^{9}$ We adjust the scale to 1 to 11 to avoid undefined values of the institutional gap, (3).

10 There are alternative measures of institutional quality that we could explore - for example, the World Bank's World Governance Indicators (which are employed in the studies by Ariu et al. (2014) and Poprawe (2015). However, in this study we are interested in the role of freedoms - economic and political; rather than the quality of governance - in determining migration decisions.
} 
Numerous studies have documented a positive correlation between economic freedom and economic growth in cross-country data (e.g., Ayal and Karras,1998; Dawson, 1998;

Gwartney et al., 1999; de Haan and Sturm, 2000; Heckelman and Stroup, 2000; Young and Sheehan, 2014). ${ }^{11}$ Economic freedom is scored, for each country, on a scale of 0 to 10 , with 10 indicating institutions that are most conducive to individual choice, competitive markets with free entry, and security in one's private property and person.

The vector $Z_{i j}$ in (1) contains our other origin-destination specific controls, and also various fixed effects (discussed below). Regarding origin-destination specific controls, we follow Mayer and Zignago (2011) and include a contiguity dummy to capture the effect of being geographic neighbors. We also control for the bilateral (log) distance between country pairs $^{12}$. We also include a colonial link dummy that takes the value of 1 for country pairs that have a past colonial relationship. Colonial relationships can imply similar cultures and other institutions, which may be associated with lower migration costs. Empirically, former colonizers tend to have particularly high migrant stocks from their former colonies. In a similar spirit, we include a common language dummy that takes a value of 1 if $20 \%$ or more of the origin and destination populations speak the same language; also a common second language dummy that takes the value of 1 if more than $9 \%$ but less than $20 \%$ of the populations speak the same language. Additionally, we control for the initial total stock of migrants from $i$ who are in $j$ are the start of the migration flow period. This stock is included to control for the positive effect that a pre-existing network of migrants from an origin can have on subsequent migration decisions of individuals from that origin. Lastly we include the

\footnotetext{
${ }^{11}$ See de Haan et al. (2006) for a comprehensive survey of the literature. The Fraser Institute's index has also be related positively to health outcomes (Stroup, 2007), political freedoms (Lawson and Clark, 2010), the extent of trust within a population (Berggren and Jordahl, 2006), labor shares (Young and Lawson, 2014), and measures of subjective well-being (Ovaska and Takashima (2006), Gehring (2003), and Nikolaev (2014)). For a comprehensive review of the empirical literature utilizing the Fraser Institute's EFW index as a control variable see Hall and Lawson (2013).

${ }^{12}$ We use the geodesic distances between major cities for this variable.
} 
per capita income gap between a destination and an origin country as a control, defined in similar fashion to (4) above. This data is collected from the World Bank. We use 1990 values for these control variables. Table 1 contains summary statistics for all variables included in our analysis. 


\subsection{Estimation Methods}

The use of two gravity model specifications is motivated by the occurrence of zero value observations for some country pairs. We apply OLS to the gravity model (1). However, when observations of (2) are zero the natural log cannot be taken. This decreases our observations from a maximum of 3,566 to a maximum of 2,246. And zero value observations can be informative. We therefore also employ the Poisson pseudo maximum likelihood method suggested by Silva and Tenreyro (2006). PPML estimates directly the nonlinear form of a gravity model, incorporating the information contained in the dependent variable observations of zero. ${ }^{13}$ Because the PPML method the nonlinear form, the dependent migration flow variable is not logged (unlike the case of OLS).

All of our estimations contain both origin and destination fixed effects. Additionally, we also control for the influence of multilateral resistance. Multilateral resistance refers to a situation where individuals from a particular origin country have migration preferences for a particular group (or nest) of destination countries (Bertoli and Fernández-Huertas Moraga, 2012 \& 2013). In the presence of multilateral resistance, the cross-section dependence can lead to biased estimates based on either OLS or PPML.

We control for multilateral resistance by following Bertoli and Fernández-Huertas Moraga (2012). They suggest including, in addition to origin and destination fixed effects, origin-nest fixed effects. The inclusion of these origin nest dummies satisfies the cross dependence requirement for PPML estimation. Intuitively, when we observe migration to a particular destination from a particular origin, we want to control for the fact that individuals in that origin may have, all else equal, a preference for migrating to a group of destination that includes that particular one. We define a group of six “nests”: (i) Asia, (ii) Middle East,

\footnotetext{
${ }^{13}$ Moreover, Silva and Tenreyro (2006) argue that the log-linearization of the traditional gravity model is likely to introduce heteroscedasticity and lead to bias estimates. PPML estimation of (2) is more consistent with the assumptions of the underlying random utility maximization model (Borjas, 1987) and less likely to introduce heteroscedasticity and bias.
} 
(iii) Latin America, (iv) Sub-Saharan Africa, (v) Western Democracies, and (vi) Eastern

Europe. ${ }^{14}$ The list of countries included in each of these nests is reported in table 2 . Based on these definitions, we report both OLS and PPML results when destination, origin, and originnest fixed effects are all included.

\section{Results}

Table 3 reports the OLS estimation results for (1) total migration, (2) college migration, and (3) non-college migration. Economic freedom differentials are a statistically significant correlate with bilateral total migration flows. However, breaking down the sample, the effect is only statistically significant for college-educated migration flows. The OLS estimated effects for political institutions are puzzling. The checks \& balances gap is significantly and positively associated with total, college, and non-college migration flows. Alternatively, the democracy gap is negatively associated with all of those migration flow samples. ${ }^{15}$

Table 4 reports PPML results for the total, college, and non-college samples. (Recall that with PPML estimation the dependent variable is not logged.) Taking into account zero value migration observations makes a substantial difference. (And these observations constitute a substantial number of observations: column 1 of table 3 is based on 2,246 observations while the analog for table 4 is 3,566.) Economic freedom now enters positively and significantly (1\% level) across the board. The point estimates for total, college, and noncollege samples are remarkably similar (7.035, 8.647, and 7.208, respectively). Neither political institutions gap enters significantly in any of the table 4 estimations.

\footnotetext{
${ }^{14}$ In principle, it would be desirable to employ a finer definition of nests. However, a basic issue with the Bertoli and Fernández-Huertas Moraga (2012) approach is the degrees of freedom that one loses by employing such a large number of dummy variables (up to 472, to be exact).

15 The point estimates on both political institutions gaps are an order of magnitude smaller than those associated with the economic freedom gap. However, the sample standard deviations for the political institutions gaps are an order of magnitude larger than that of the economic freedom gap. (See table 1.)
} 
To put these estimated economic freedom gap effects quantitatively in perspective, note that since the gap is a ratio the coefficient estimate is essentially an elasticity. ${ }^{16}$ Starting from identical economic freedom levels in an origin and potential destination, if the EFW score of the destination increases by $10 \%$ then, all else equal, we expect that the bilateral migration flow from that origin to that destination increases by somewhere between 70 and 80\%. Using the mean bilateral migration flow (about 371) as a benchmark, that amounts to between 259 and 297 additional migrants. This is a large effect.

We also note that the per capita income gap appears to be more important for college migrants than their non-college counterparts. In the OLS results (table 3) the income gap only enters significantly for non-college and the point estimate is much larger than that for college (16.566 versus 2.977). Once we take into account the information contained in the zero flow observations, the point estimate for college is more than twice that as for noncollege (28.236 versus 13.746). This result is consistent with destination-origin income differentials being based in large part on the returns to human capital. College educated individuals are more drawn by a given income differential because by migrating they are more likely to experience an increase in their own income that is commensurate with (or greater than) that differential. ${ }^{17}$

Table 4 suggests that for migrants of all education levels destination-origin differentials in economic freedom are significant determinants of bilateral migration flows ${ }^{18}$.

\footnotetext{
${ }^{16}$ Even though PPML estimation does not use the log of the migration flow as the dependent variable (so that observations with value of zero can be utilized) the coefficients can be interpreted similarly to those of the OLS estimation because PPML is based on the non-linear form of the gravity model.

${ }^{17}$ Income gaps and economic freedom gaps are correlated with one another. (The simple correlation between the two variables in our sample is 0.3938 .) This creates a collinearity concern in our estimations. However, while this might inflate the standard error on the income gap estimate it is unclear as to why this would be a particular problem in the non-college migration estimations relative to the college migration estimations.

${ }^{18}$ As a robustness check, we include two more tables in the Appendix of this manuscript. Appendix A1, presents the PPML estimations analogus to table 4 with only including non-zero observations. (same observations as the OLS estimations in table 3). Tabel A2, shows the result excluding the flows to the United States.
} 
The EFW index has 5 constituent areas: size of government, legal system and property rights, access to sound money, freedom to trade internationally, and regulation of business, credit, and labor markets. Table 5 reports results for PPML estimations that are analogous to those of table 4 except that the 5 EFW areas are included in the estimations individually. Overall, economic freedom is still significant why the political institutions gaps are not. However, we specifically see that three EFW areas enter significantly into the total, college, and noncollege estimations: property, sound money, and regulation. Furthermore, the largest effects are associated with the legal system and property rights area, and those effects are remarkably similar across the total, college, and non-college subsamples (point estimates of 1.550, 1.592, and 1.809, respectively).

We also note that income gap results reported in table 5 are consistent with those from table 4. The point estimate for college is again much larger than that for non-college (42.498 versus 16.772). Again, this is consistent with destination-origin income differentials based largely on returns to human capital.

\section{Concluding Discussion}

In this paper we employ data from 77 countries during the 1990-2000 time period to explore emigrant self-selection according to institutional quality. In particular, we ask whether destination-origin differentials in measures of political and/or economic institutional quality are determinants of bilateral migration flows.

Our tentative answer is in line with Ashby’s (2010) earlier study. Relative increases in economic freedom are significantly attractive to potential migrants; increases in political freedom, all else equal, not so much. Though we echo Ashby’s conclusion along these lines, we demonstrate that the result is robust to a larger sample of countries and examining migration flows over a substantially long (10-year; 1990-2000) period. 
We also ask whether the effects are different for college-educated versus non-college educated migrants. In regards to economic freedom it appears that the answer is: no. Economic freedom differentials are associated with increased migration in regards to both relatively low- and high-skilled individuals.

While we do not find different effects across educational attainment types, we do find them across the different dimensions of economic freedom. In particular, environments of sound money, low regulation, and property rights secured under the rule-of-law are, all else equal, attractive to potential migrants. The estimated effect of strong property rights is particularly large.

Emma Lazarus famously wrote: “Give me your tired, your poor, Your huddled masses yearning to breathe free[.]" If the Statue of Liberty is selling, our results suggest that the potential migrants of the world are buying. All else equal, our results suggest that migrants look to exit their origins towards destination where they breathe more economically free. 


\section{References}

Ariu, A., Docquier, F., Squicciarini, M. P. 2014. Governance quality and net migration flows. Working Paper.

(http://perso.uclouvain.be/frederic.docquier/filePDF/ADS_BrainBalance.pdf).

Ashby, N. J. Economic freedom and migration flows between U.S. states. Southern Economic Journal 73, 677-697.

Ashby, N. J. 2010. Freedom and international migration. Southern Economic Journal 77, 49-62.

Ayal, E. B., Karras, G. 1998. Components of economic freedom and growth: an empirical study. Journal of Developing Areas 32, 327-338.

Bang, J.T., Mitra, A. 2011., Gender bias and the female brain drain. Applied Economics Letters 18, 829-833.

Baudassé, T., Bazillier, R. 2014. Gender inequality and emigration: push factor or selection process. International Economics 139, 19-47.

Beck, T. Keefer, P. E., Clarke, G. R. Walsh, P., 2010. Database of Political Institutions. World Bank, Washington.

Bein, M., Docquier, F., Ozden, C. 2011. Diasporas. Journal of Development Economics 95, 30-41.

Belot, M. V. K., Hatton, T. J. 2012. Immigrant selection in the OECD. Scandinavian Journal of Economics 114, 1105-1128.

Berggren, N., Jordahl, H. 2006. Free to trust: economic freedom and social capital. Kyklos 59, 141-169.

Bertocchi, G., Strozzi, C. 2008. International migration and the role of institutions. Public Choice 137, 81-102.

Bertoli, S., Hernández-Huertas Moraga, J. 2012. Visa policies, networks and the 
cliff at the border. IZA Discussion Paper 7094, (http://ftp.iza.org/dp7094.pdf).

Bertoli, S., Fernández-Huertas Moraga, J., 2013. Multilateral resistance to migration. Journal of Development Economics 102, 79-100.

Bertoli, S., Brückner, H., Fernández-Huertas Moraga, J. 2013. The European crisis and migration to Germany: expectations and the diversion of migration flows. IZA Discussion Paper 7170, (http://ftp.iza.org/dp7170.pdf).

Borjas, G. J. 1987. Self-selection and the earnings of immigrants. American Economic Review 77, 531-553.

Borjas, G. J., 1994. The economics of immigration. Journal of Economic Literature 32, 1667-1717.

Borjas, G. J., 1999. The economic progress of immigrants. in Handbook of Labor Economics (Ashenfelter and Card, eeds.). Elsevier, North Holland.

Borjas, G. J., 2014. Imigration Economics. Cambridge: Harvard University Press.

Borjas, G. J., 2015. Immigration and globalization: a review essay. Journal of Economic Literature (forthcoming).

Brückner, H., Deffort, C. 2009. Inequality and the self-selection of international migrants: theory and new evidence. International Journal of Manpower 30, 742-764.

Clark, J. R., Lawson, R., Nowrasteh, A., Powell, B., Murphy, R. 2015. Does immigration impact institutions? Public Choice 163: 321-335.

Collier, P., 2013. Exodus: how migration is changing out world. Oxford: Oxford University Press.

Dawson, J. W. 1998. Institutions, investment, and growth: new cross-country and panel data evidence. Economic Inquiry 36, 603-619.

de Haan, J., Sturm, J-E. 2000. On the relationship between economic freedom and economic growth. European Journal of Political Economy 16, 215-241. 
de Haan, J., Lundström, S., Sturm, J-E. 2006. Market-oriented institutions and policies and economic growth. Journal of Economic Surveys 20, 157-191.

Docquier, F., Rapoport, H. 2012. Globalization, brain drain and development. Journal of Economic Literature. 50, 681-730.

Docquier, F., 2006. Brain drain and inequality across nations. IZA Discussion Paper No. 2440, (http://ftp.iza.org/dp2440.pdf).

Docquier, F. Lodigiani, E., Rapoport, H., Schiff, M. 2014. Emigration and democracy. CEPREMAP Working Paper, (http://www.cepremap.fr/depot/docweb/docweb1406.pdf).

Docquier, F., Lowell, B. L., Marfouk, A., 2009. A gendered assessment of the brain drain. Population and Development Review 35, 297-321.

Dumont, J. C., Martin, J.P., \& Spielvogel, G. 2007. Women on the move: the neglected gender dimension of the brain drain. IZA Discussion Papers No. 2920, (http://ftp.iza.org/dp2920.pdf).

Ferrant, G., Tuccio, M. 2013. South-south emigration and discriminatory social institutions: a two-way relationship. Working Paper, (http://www.ferdi.fr/sites/www.ferdi.fr/files/ferrant_tuccio.pdf).

Gehring, K., 2013. Who benefits from economic freedom? unraveling the effect of economic freedom on subjective well-being. World Development 50, 74-90.

Gwartney, J., Lawson, R., Holcombe, R. 1999. Economic freedom and the environment for economic growth. Journal of Institutional and Theoretical Economics 155, 643-663.

Gwartney, J., Lawson, R., Hall, J. 2014. Economic Freedom of the World: 2014 Annual Report. Fraser Institute, Vancouver.

Hall, J. C., Lawson, R. A., 2013. Economic freedom of the world: an accounting of the literature. Contemporary Economic Policy 32, 1-19. 
Heckelman, J. C., Stroup, M. D. 2000. Which economic freedoms contribute to growth? Kyklos 53, 527-544.

Hirschman, A. O. 1970. Exit, voice and loyalty: responses to decline in firms. in Organizations and States. Harvard University Press, Cambridge.

Hirschman, A. O. 1993. Exit, voice, and the fate of the German Democratic Republic: an essay in conceptual history. World Politics 45, 173-202.

Kababegovic, A., McMahon, F., Mitchell, G. 2005. Economic Freedom of North America. Fraser Institute, Vancouver.

Karemara, D., Oguledo, V. I., Davis, B. 2000. A gravity model analysis of international migration to North America. Applied Economics 32, 1745-1755.

Keefer, P., Stasavage, D., 2003. The limits of delegation: veto players, central bank independence and the credibility of monetary policy. American Political Science Review 97, 407-423.

Lawson, R. A., Clark, J. R. 2010. Examining the Hayek-Friedman hypothesis on economic and political freedom. Journal of Economic Behavior and Organization 3, 230-239.

Lodigiani, E., \& Salomone, S., 2012. Migration-induced transfers of norms: the case of female political empowerment. SSRN Working Paper, (http://papers.ssrn.com/sol3/papers.cfm?abstract_id=2214978).

Marchiori, L., Shen, I-L, Docquier, F. 2012. Brain drain in globalization: a general equilibrium analysis from the sending countries’ perspective. Economic Inquiry 51, 1582-1602.

Marshall, G. M., Jaggars, K. 2010. Polity IV Project: Political Regime Characteristics and Transitions, 1800-2008. Polity IV.

Mayer, T., Zignago, S., 2011. Notes on CEPII’s distances measures (GeoDist). CEEPII Working Paper 2011-25, (www.cepii.fr/anglaisgraph/bdd/distances.htm). 
McKenzie, D., Theoharides, C., Yang, D. 2013. Distortions in the international migrant labor market: evidence from Filipino migration and wage responses to destination country economic shocks. American Economic Journal: Applied 6: 49-75.

Melkumian, A. V., 2006. A gravity model of legal immigration to the United States. Unpublished Paper, (http://www.jepson.gonzaga.edu/JEDBP/Volumes/gravmodfin1\%20\%283\%29.pdf).

Naghsh Nejad, M., 2013. Institutionalized inequality and brain drain: an empirical study of the effects of women's rights on the gender gap in high-skilled migration. IZA Discussion Paper 7864, (http://papers.ssrn.com/sol3/papers.cfm?abstract_id=2116618).

Naghsh Nejad, M., Young, A. T., 2015. Female brain drains and women’s rights gaps: analysis of bilateral migration flows. SSRN Working Paper, (http://papers.ssrn.com/sol3/papers.cfm?abstract_id=2420712).

Nikolaev, B., 2014. Economic freedom \& subjective well-being - revisiting the relationship. Working Paper (http://borisnikolaev.com/wp-content/uploads/2014/05/FREE-SWB_final.pdf).

Nikolova, M., Graham, C. L. 2015. In transit: the well-being of migrants from transition and post-transition countries. Journal of Economics Behavior and Organization 112, 164-186.

North, D. C., 1990. Institutions, Institutional Change and Economic Performance. Cambridge University Press, Cambridge.

Ortega, F., Peri, G., 2013. The role of income and immigration policies in attracting international migrants. Migration Studies 1, 47-74.

Ovaska, T., Takashima, R. 2006. Economic policy and the level of self-perceived wellbeing: an international comparison. Journal of Socio-Economics 35, 308-325. 
Poprawe, M. 2015. On the relationship between corruption and migration: empirical evidence from a gravity model of migration. Public Choice 163, 337-354.

Roy, A. D. 1951. Some thoughts on the distribution of earnings. Oxford Economic Papers 3, 135-146.

Silva, J. M., Santos, C., Tenreyro, S. 2006. The log of gravity. Review of Economics and Statistics 88, 641-658.

Spilimbergo, A. 2009. Democracy and foreign education. American Economic Review 99, 528-543.

Stroup, M. D. 2007. Economic freedom, democracy, and the quality of life. World Development 35, 52-66.

Vogler, M., Rotte, R. 2000. The effects of development on migration: theoretical issues and new empirical evidence. Journal of Population Economics 13, 485-508.

Young, A. T., Lawson, R. A., 2014. Capitalism and labor shares: a cross-country panel study. European Journal of Political Economy 33, 20-36.

Young, A. T., Sheehan, K. M., 2014. Foreign aid, institutional quality, and growth. European Journal of Political Economy. 36, 195-208. 
Table 1

Summary statistics for variables included in estimations.

\begin{tabular}{|c|c|c|c|c|c|}
\hline Variable & Minimum & Maximum & Mean & Std. Deviation & Observations \\
\hline Total Migration & 0.000 & $366,608.812$ & 371.361 & $6,232.187$ & 3,812 \\
\hline College Migration & 0.000 & $56,608.801$ & 158.604 & $1,461.266$ & 3,812 \\
\hline Non-college Migration & 0.000 & $310,000.000$ & 236.665 & $5,144.910$ & 3,812 \\
\hline Economic Freedom Gap & 0.320 & 3.124 & 1.086 & 0.406 & 3,812 \\
\hline Democracy gap & 0.091 & 11.000 & 2.274 & 3.177 & 3,812 \\
\hline Checks \& Balances Gap & 0.111 & 9.000 & 1.557 & 1.415 & 3,812 \\
\hline Income Gap & 0.587 & 1.703 & 1.024 & 0.191 & 3,812 \\
\hline Log Distances & 5.153 & 9.892 & 8.764 & 0.870 & 3,812 \\
\hline Colonial Link & 0.000 & 1.000 & 0.027 & 0.162 & 3,812 \\
\hline Common Language & 0.000 & 1.000 & 0.168 & 0.374 & 3,812 \\
\hline Common Second Language & 0.000 & 1.000 & 0.192 & 0.394 & 3,812 \\
\hline Contiguity & 0.000 & 1.000 & 0.032 & 0.175 & 3,812 \\
\hline Total Migrant Stock 1990 (in 10,000) & 0.000 & 2.653 & 0.009 & 0.065 & 3,812 \\
\hline
\end{tabular}

Notes: observation numbers are based on observations of a variable that are included in any estimation. This is why the maximum number of observations associated with any estimation is 3,566 but all observations in this table all 3,812. 
Table 2

Countries included in the analysis; grouped by "nests".

\begin{tabular}{|c|c|c|c|c|c|}
\hline Asia & Middle East & Latin America & Sub-Saharan Africa & Western Democracies & Eastern European \\
\hline China & Algeria & Argentina & Angola & Australia & Hungry \\
\hline Indonesia & Egypt & Bahamas & Cote d'Ivoire & Austria & Poland \\
\hline India & Morocco & Barbados & Central African Rep. & Belgium & Romania \\
\hline Japan & Tunisia & Belize & Ghana & Canada & Russia \\
\hline Malaysia & Turkey & Bolivia & Kenya & Denmark & \\
\hline Philippines & & Brazil & Mauritius & Finland & \\
\hline Singapore & & Chile & Nigeria & France & \\
\hline Sri Lanka & & Colombia & Zambia & Germany & \\
\hline South Korea & & Costa Rica & Zimbabwe & Greece & \\
\hline Thailand & & Cuba & & Iceland & \\
\hline & & Dominican Republic & & Ireland & \\
\hline & & Ecuador & & Italy & \\
\hline & & El Salvador & & Netherlands & \\
\hline & & Guatemala & & New Zealand & \\
\hline & & Guyana & & Norway & \\
\hline & & Haiti & & Portugal & \\
\hline & & Honduras & & Spain & \\
\hline & & Jamaica & & Sweden & \\
\hline & & Jamaica & & Switzerland & \\
\hline & & Mexico & & UK & \\
\hline & & Nicaragua & & US & \\
\hline & & Panama & & & \\
\hline & & Paraguay & & & \\
\hline & & Peru & & & \\
\hline & & Suriname & & & \\
\hline & & Trinidad \& Tobago & & & \\
\hline & & Uruguay & & & \\
\hline & & Venezuela & & & \\
\hline
\end{tabular}


Table 3

OLS fixed effects regressions of migration flows on institutional variables.

\begin{tabular}{|c|c|c|c|}
\hline & $\begin{array}{c}\text { (1) } \\
\text { Total Migration }\end{array}$ & $\begin{array}{c}(2) \\
\text { College Migration }\end{array}$ & $\begin{array}{c}\text { (3) } \\
\text { Non-college Migration }\end{array}$ \\
\hline \multirow[t]{2}{*}{ Economic Freedom Gap } & $1.309^{* *}$ & $1.791^{* * *}$ & 0.368 \\
\hline & $(0.634)$ & $(0.547)$ & $(0.820)$ \\
\hline \multirow[t]{2}{*}{ Checks \& Balances Gap } & $0.150^{* * *}$ & $0.144^{* * *}$ & $0.224^{* * *}$ \\
\hline & $(0.065)$ & $(0.054)$ & $(0.076)$ \\
\hline \multirow[t]{2}{*}{ Democracy Gap } & $-0.102^{* *}$ & $-0.070^{* *}$ & $-0.185^{* * *}$ \\
\hline & $(0.040)$ & $(0.035)$ & $(0.050)$ \\
\hline \multirow[t]{2}{*}{ Income Gap } & 4.009 & 2.977 & $16.566^{* * *}$ \\
\hline & (4.190) & (3.218) & $(5.445)$ \\
\hline \multirow[t]{2}{*}{ Log Distances } & $-1.212^{* * *}$ & $-0.938^{* * *}$ & $-1.137^{* * *}$ \\
\hline & $(0.063)$ & $(0.051)$ & $(0.076)$ \\
\hline \multirow[t]{2}{*}{ Colonial Link } & $0.974^{* * *}$ & $1.096^{* * *}$ & $1.362^{* * *}$ \\
\hline & $(0.187)$ & $(0.152)$ & $(0.234)$ \\
\hline \multirow[t]{2}{*}{ Common Language } & $0.455^{* *}$ & $0.604^{* * *}$ & -0.200 \\
\hline & $(0.214)$ & $(0.170)$ & $(0.258)$ \\
\hline \multirow{2}{*}{ Common Second Language } & $0.498^{* *}$ & $0.498^{* * *}$ & $1.057^{* * *}$ \\
\hline & $(0.205)$ & $(0.161)$ & $(0.248)$ \\
\hline \multirow[t]{2}{*}{ Contiguity } & $0.324^{*}$ & 0.181 & $0.815^{* * *}$ \\
\hline & $(0.169)$ & $(0.133)$ & $(0.198)$ \\
\hline \multirow[t]{2}{*}{ Total Migrant Stock 1990} & $0.022^{* * *}$ & $0.015^{* * *}$ & $0.027^{* * *}$ \\
\hline & $(0.004)$ & $(0.003)$ & $(0.004)$ \\
\hline Origin Fixed Effects & $\mathrm{Y}$ & $\mathrm{Y}$ & $\mathrm{Y}$ \\
\hline Destination Fixed Effects & $\mathrm{Y}$ & $\mathrm{Y}$ & $\mathrm{Y}$ \\
\hline Origin*Nest Fixed Effects & $\mathrm{Y}$ & $\mathrm{Y}$ & $\mathrm{Y}$ \\
\hline Observations & 2246 & 2197 & 1926 \\
\hline $\mathrm{R}^{2}$ & 0.840 & 0.875 & 0.804 \\
\hline
\end{tabular}

Notes: ${ }^{* *}$, and ${ }^{* * *}$ denote statistical significance at the 10,5 , and $1 \%$ levels, respectively. Clustered standard errors are in parentheses. 
Table 4

PPML fixed effects regressions of migration flows on institutional variables.

\begin{tabular}{|c|c|c|c|}
\hline & $\begin{array}{c}(1) \\
\text { Total Migration }\end{array}$ & $\begin{array}{c}\text { (2) } \\
\text { College Migration }\end{array}$ & $\begin{array}{c}\text { (3) } \\
\text { Non-college Migration }\end{array}$ \\
\hline \multirow[t]{2}{*}{ Economic Freedom Gap } & $7.035^{* * *}$ & $8.647^{* * *}$ & $7.208^{* * *}$ \\
\hline & $(1.413)$ & $(1.723)$ & $(1.613)$ \\
\hline \multirow[t]{2}{*}{ Checks \& Balances Gap } & -0.003 & 0.011 & 0.063 \\
\hline & $(0.091)$ & $(0.090)$ & $(0.117)$ \\
\hline \multirow{2}{*}{ Democracy Gap } & 0.002 & -0.090 & 0.033 \\
\hline & $(0.080)$ & $(0.069)$ & $(0.091)$ \\
\hline \multirow[t]{2}{*}{ Income Gap } & 9.122 & $28.236^{*}$ & 13.746 \\
\hline & (8.138) & $(14.412)$ & $(8.906)$ \\
\hline \multirow[t]{2}{*}{ Log Distances } & $-1.223^{* * *}$ & $-0.748^{* * *}$ & $-1.308^{* * *}$ \\
\hline & $(0.095)$ & $(0.115)$ & $(0.122)$ \\
\hline \multirow[t]{2}{*}{ Colonial Link } & $0.517^{* *}$ & $0.560^{* *}$ & $0.642^{* *}$ \\
\hline & $(0.240)$ & $(0.233)$ & $(0.258)$ \\
\hline \multirow[t]{2}{*}{ Common Language } & 0.014 & $0.552^{* *}$ & $-0.642^{* *}$ \\
\hline & $(0.255)$ & $(0.218)$ & $(0.290)$ \\
\hline \multirow[t]{2}{*}{ Common Second Language } & $1.352^{* * *}$ & $0.932^{* * *}$ & $1.816^{* * *}$ \\
\hline & $(0.198)$ & $(0.197)$ & $(0.261)$ \\
\hline \multirow[t]{2}{*}{ Contiguity } & -0.384 & -0.231 & -0.097 \\
\hline & $(0.243)$ & $(0.218)$ & $(0.277)$ \\
\hline \multirow[t]{2}{*}{ Total Migrant Stock 1990} & $1.909^{* * *}$ & $1.737^{* * *}$ & $2.321^{* * *}$ \\
\hline & $(0.209)$ & $(0.411)$ & $(0.313)$ \\
\hline Origin Fixed Effects & $\mathrm{Y}$ & $\mathrm{Y}$ & $\mathrm{Y}$ \\
\hline Destination Fixed Effects & $\mathrm{Y}$ & $\mathrm{Y}$ & $\mathrm{Y}$ \\
\hline Origin*Nest Fixed Effects & $\mathrm{Y}$ & $\mathrm{Y}$ & $\mathrm{Y}$ \\
\hline Observations & 3,566 & 3,531 & 3,506 \\
\hline $\mathrm{R}^{2}$ & 0.990 & 0.926 & 0.995 \\
\hline
\end{tabular}

Notes: ${ }^{* *}$, and ${ }^{* * *}$ denote statistical significance at the 10,5 , and $1 \%$ levels, respectively. Clustered standard errors are in parentheses. 
Table 5

PPML fixed effects regressions of migration flows on institutional variables.

\begin{tabular}{|c|c|c|c|}
\hline & $\begin{array}{c}\text { (1) } \\
\text { Total Migration }\end{array}$ & $\begin{array}{c}\text { (2) } \\
\text { College Migration }\end{array}$ & $\begin{array}{c}\text { (3) } \\
\text { Non-college Migration }\end{array}$ \\
\hline Size of Government Gap & $\begin{array}{c}0.439 \\
(0.341)\end{array}$ & $\begin{array}{c}0.147 \\
(0.334)\end{array}$ & $\begin{array}{c}0.240 \\
(0.445)\end{array}$ \\
\hline Property Rights Gap & $\begin{array}{l}1.550^{* *} \\
(0.664)\end{array}$ & $\begin{array}{l}1.592^{*} \\
(0.899)\end{array}$ & $\begin{array}{l}1.809^{* * *} \\
(0.786)\end{array}$ \\
\hline Sound Money Gap & $\begin{array}{l}0.322^{* * *} \\
(0.126)\end{array}$ & $\begin{array}{l}0.411^{* * *} \\
(0.142)\end{array}$ & $\begin{array}{c}0.387^{* * *} \\
(0.135)\end{array}$ \\
\hline Trade Gap & $\begin{array}{c}-0.419 \\
(0.294)\end{array}$ & $\begin{array}{c}-0.214 \\
(0.385)\end{array}$ & $\begin{array}{c}-0.211 \\
(0.356)\end{array}$ \\
\hline Regulation Gap & $\begin{array}{c}0.997^{*} \\
(0.536)\end{array}$ & $\begin{array}{l}1.281^{* *} \\
(0.539)\end{array}$ & $\begin{array}{c}0.990^{*} \\
(0.560)\end{array}$ \\
\hline Checks \& Balances Gap & $\begin{array}{l}-0.029 \\
(0.093)\end{array}$ & $\begin{array}{l}-0.036 \\
(0.086)\end{array}$ & $\begin{array}{c}0.044 \\
(0.119)\end{array}$ \\
\hline Democracy Gap & $\begin{array}{c}0.037 \\
(0.087)\end{array}$ & $\begin{array}{c}-0.086 \\
(0.071)\end{array}$ & $\begin{array}{c}0.074 \\
(0.098)\end{array}$ \\
\hline Income Gap & $\begin{array}{l}16.367^{*} \\
(8.808)\end{array}$ & $\begin{array}{l}42.498^{* * *} \\
(15.867)\end{array}$ & $\begin{array}{l}16.772^{*} \\
(9.398)\end{array}$ \\
\hline Log Distances & $\begin{array}{l}-1.221^{* * *} \\
(0.101)\end{array}$ & $\begin{array}{c}-0.732^{* * *} \\
(0.127)\end{array}$ & $\begin{array}{l}-1.299^{* * *} \\
(0.129)\end{array}$ \\
\hline Colonial Link & $\begin{array}{l}0.581^{* *} \\
(0.254)\end{array}$ & $\begin{array}{l}0.592^{* *} \\
(0.251)\end{array}$ & $\begin{array}{l}0.750^{* * *} \\
(0.277)\end{array}$ \\
\hline Common Language & $\begin{array}{c}-0.058 \\
(0.262)\end{array}$ & $\begin{array}{l}0.468^{* *} \\
(0.231)\end{array}$ & $\begin{array}{c}-0.700^{* *} \\
(0.292)\end{array}$ \\
\hline Common Second Language & $\begin{array}{l}1.455^{* * *} \\
(0.206)\end{array}$ & $\begin{array}{l}1.035^{* * *} \\
(0.209)\end{array}$ & $\begin{array}{l}1.893^{* * *} \\
(0.272)\end{array}$ \\
\hline Contiguity & $\begin{array}{c}0.439 \\
(0.341)\end{array}$ & $\begin{array}{c}0.147 \\
(0.334)\end{array}$ & $\begin{array}{c}0.240 \\
(0.445)\end{array}$ \\
\hline Total Migrant Stock 1990 & $\begin{array}{l}1.550^{* *} \\
(0.664)\end{array}$ & $\begin{array}{l}1.592^{*} \\
(0.899)\end{array}$ & $\begin{array}{l}1.809^{* *} \\
(0.786)\end{array}$ \\
\hline Origin Fixed Effects & $\mathrm{Y}$ & $\mathrm{Y}$ & $\mathrm{Y}$ \\
\hline Destination Fixed Effects & $\mathrm{Y}$ & $\mathrm{Y}$ & $\mathrm{Y}$ \\
\hline Origin*Nest Fixed Effects & $\mathrm{Y}$ & $\mathrm{Y}$ & $\mathrm{Y}$ \\
\hline Observations & 3,517 & 3,491 & 3,473 \\
\hline $\mathrm{R}^{2}$ & 0.989 & 0.922 & 0.995 \\
\hline
\end{tabular}

Notes: ${ }^{*}{ }^{* *}$, and $* * *$ denote statistical significance at the 10,5 , and $1 \%$ levels, respectively. Clustered standard errors are in parentheses. 
Appendix:

Table A1: PPML fixed effects regressions of migration flows on institutional variables using only non-zero observations.

\begin{tabular}{lccc}
\hline & $(1)$ & $(2)$ & $(3)$ \\
& Total Migration & College Migration & Non-college Migration \\
\hline Economic Freedom Gap & $5.027^{* * *}$ & $7.520^{* * *}$ & $4.063^{* * *}$ \\
Checks \& Balances Gap & $(1.334)$ & $(1.494)$ & $(1.331)$ \\
& -0.014 & 0.011 & -0.005 \\
Democracy Gap & $(0.088)$ & $(0.090)$ & $(0.109)$ \\
& -0.034 & -0.073 & 0.157 \\
Income Gap & $(0.094)$ & $(0.067)$ & $(0.126)$ \\
& 7.806 & $21.765^{* *}$ & 6.385 \\
Log Distances & $(8.158)$ & $(12.661)$ & $(9.532)$ \\
& $-1.201^{* * *}$ & $-0.666^{* * *}$ & $-1.062^{* * *}$ \\
Colonial Link & $(0.103)$ & $(0.103)$ & $(0.113)$ \\
& 0.369 & $0.521^{* *}$ & $0.975^{* * *}$ \\
Common Language & $(0.240)$ & $(0.243)$ & $(0.249)$ \\
& 0.298 & $0.562^{* *}$ & $-0.774^{* * *}$ \\
Common Second Language & $(0.258)$ & $(0.221)$ & $(0.287)$ \\
& $0.980^{* * *}$ & $0.809^{* * *}$ & $1.685^{* * *}$ \\
Contiguity & $(0.201)$ & $(0.193)$ & $(0.252)$ \\
& -0.137 & -0.262 & 0.090 \\
Total Migrant Stock 1990 & $(0.235)$ & $(0.209)$ & $(0.235)$ \\
& $2.349^{* * *}$ & $1.975^{* * *}$ & $2.949^{* * *}$ \\
\hline Origin Fixed Effects & $(0.314)$ & $(0.430)$ & $(0.419)$ \\
Destination Fixed Effects & $\mathrm{Y}$ & $\mathrm{Y}$ & $\mathrm{Y}$ \\
Origin*Nest Fixed Effects & $\mathrm{Y}$ & $\mathrm{Y}$ & $\mathrm{Y}$ \\
\hline Observations & $\mathrm{Y}$ & $\mathrm{Y}$ & 1926 \\
RSquard & 2246 & 2197 & 0.997 \\
\hline Standard errors in parentheses & 0.992 & 0.932 & \\
${ }^{*} p<0.10{ }^{* * *} p<0.05,{ }^{* * *} p<.01$ & & &
\end{tabular}


Table A2: PPML fixed effects regressions of migration flows on institutional variables excluding flow to the US.

\begin{tabular}{|c|c|c|c|}
\hline & $\begin{array}{c}\text { (1) } \\
\text { Total Migration }\end{array}$ & $\begin{array}{c}(2) \\
\text { College Migration }\end{array}$ & $\begin{array}{c}\text { (3) } \\
\text { Non-college Migration }\end{array}$ \\
\hline Economic Freedom Gap & $\begin{array}{l}4.817^{* * *} \\
(1.585)\end{array}$ & $\begin{array}{l}6.431^{* * *} \\
(1.827)\end{array}$ & $\begin{array}{l}5.579^{* * *} \\
(1.692)\end{array}$ \\
\hline Checks \& Balances Gap & $\begin{array}{l}-0.027 \\
(0.092)\end{array}$ & $\begin{array}{l}-0.022 \\
(0.072)\end{array}$ & $\begin{array}{c}0.000 \\
(0.118)\end{array}$ \\
\hline Democracy Gap & $\begin{array}{c}0.029 \\
(0.073)\end{array}$ & $\begin{array}{l}-0.070 \\
(0.057)\end{array}$ & $\begin{array}{c}0.019 \\
(0.082)\end{array}$ \\
\hline Income Gap & $\begin{array}{l}1.197 \\
(6.318)\end{array}$ & $\begin{array}{l}12.369 \\
(7.898)\end{array}$ & $\begin{array}{l}7.631 \\
(7.617)\end{array}$ \\
\hline Log Distances & $\begin{array}{l}-1.109^{* * * *} \\
(0.104)\end{array}$ & $\begin{array}{c}-0.746^{* * *} \\
(0.080)\end{array}$ & $\begin{array}{c}-1.107^{* * *} \\
(0.128)\end{array}$ \\
\hline Colonial Link & $\begin{array}{l}0.927^{* * *} \\
(0.238)\end{array}$ & $\begin{array}{l}0.874^{* * *} \\
(0.203)\end{array}$ & $\begin{array}{l}0.902^{* * *} \\
(0.274)\end{array}$ \\
\hline Common Language & $\begin{array}{l}-0.005 \\
(0.318)\end{array}$ & $\begin{array}{l}0.708^{* * *} \\
(0.267)\end{array}$ & $\begin{array}{l}-0.159 \\
(0.359)\end{array}$ \\
\hline Common Second Language & $\begin{array}{l}1.053^{* * * *} \\
(0.322)\end{array}$ & $\begin{array}{c}0.413 \\
(0.268)\end{array}$ & $\begin{array}{l}1.163^{* * *} \\
(0.369)\end{array}$ \\
\hline Contiguity & $\begin{array}{l}-0.207 \\
(0.232)\end{array}$ & $\begin{array}{l}-0.162 \\
(0.185)\end{array}$ & $\begin{array}{c}0.074 \\
(0.271)\end{array}$ \\
\hline total1900d & $\begin{array}{l}2.122^{* * *} \\
(0.366)\end{array}$ & $\begin{array}{l}2.462^{* * *} \\
(0.385)\end{array}$ & $\begin{array}{l}2.589^{* * *} \\
(0.441)\end{array}$ \\
\hline Origin Fixed Effects & $\mathrm{Y}$ & $\mathrm{Y}$ & $\mathrm{Y}$ \\
\hline Destination Fixed Effects & $\mathrm{Y}$ & $\mathrm{Y}$ & $\mathrm{Y}$ \\
\hline Origin*Nest Fixed Effects & $\mathrm{Y}$ & $\mathrm{Y}$ & $\mathrm{Y}$ \\
\hline Observations & 3502 & 3467 & 3442 \\
\hline RSquard & 0.807 & 0.684 & 0.874 \\
\hline
\end{tabular}

in parentheses

${ }^{*} p<0.10,{ }^{* *} p<0.05,{ }^{* * *} p<.01$ 